\title{
Antioxidant properties of xanthones from Calophyllum brasiliense: prevention of oxidative damage induced by $\mathrm{FeSO}_{4}$
}

Tonali Blanco-Ayala ${ }^{1}$, Rafael Lugo-Huitrón ${ }^{1}$, Elizabeth M Serrano-López ${ }^{1}$, Ricardo Reyes-Chilpa², Edgar Rangel-López ${ }^{3}$, Benjamín Pineda ${ }^{4}$, Omar Noel Medina-Campos ${ }^{5}$, Laura Sánchez-Chapul ${ }^{6}$, Enrique Pinzón Trejo-Solis Cristina ${ }^{4}$, Daniela Silva-Adaya ${ }^{1}$, José Pedraza-Chaverrí ${ }^{5}$, Camilo Ríos ${ }^{1}$, Verónica Pérez de la Cruz ${ }^{1 *}$ and Mónica Torres-Ramos ${ }^{8^{*}}$

\begin{abstract}
Background: Reactive oxygen species (ROS) are important mediators in a number of degenerative diseases. Oxidative stress refers to the imbalance between the production of ROS and the ability to scavenge these species through endogenous antioxidant systems. Since antioxidants can inhibit oxidative processes, it becomes relevant to describe natural compounds with antioxidant properties which may be designed as therapies to decrease oxidative damage and stimulate endogenous cytoprotective systems. The present study tested the protective effect of two xanthones isolated from the heartwood of Calophyllum brasilienses against $\mathrm{FeSO}_{4}$-induced toxicity.

Methods: Through combinatory chemistry assays, we evaluated the superoxide $\left(\mathrm{O}_{2}^{\bullet-}\right)$, hydroxyl radical $\left(\mathrm{OH}^{\bullet}\right)$, hydrogen peroxide $\left(\mathrm{H}_{2} \mathrm{O}_{2}\right)$ and peroxynitrite $\left(\mathrm{ONOO}^{-}\right)$scavenging capacity of jacareubin (xanthone III) and 2-(3,3dimethylallyl)-1,3,5,6-tetrahydroxyxanthone (xanthone V). The effect of these xanthones on murine DNA and bovine serum albumin degradation induced by an $\mathrm{OH} \cdot$ generator system was also evaluated. Additionally, we investigated the effect of these xanthones on ROS production, lipid peroxidation and glutathione reductase (GR) activity in $\mathrm{FeSO}_{4}$-exposed brain, liver and lung rat homogenates.

Results: Xanthone $\mathrm{V}$ exhibited a better scavenging capacity for $\mathrm{O}_{2}^{\bullet-}, \mathrm{ONOO}^{-}$and $\mathrm{OH}^{\bullet}$ than xanthone $\mathrm{II}$, although both xanthones were unable to trap $\mathrm{H}_{2} \mathrm{O}_{2}$. Additionally, xanthones III and $\mathrm{V}$ prevented the albumin and DNA degradation induced by the $\mathrm{OH}^{\bullet}$ generator system. Lipid peroxidation and $\mathrm{ROS}$ production evoked by $\mathrm{FeSO}_{4}$ were decreased by both xanthones in all tissues tested. Xanthones III and V also prevented the GR activity depletion induced by pro-oxidant activity only in the brain.
\end{abstract}

Conclusions: Altogether, the collected evidence suggests that xanthones can play a role as potential agents to attenuate the oxidative damage produced by different pro-oxidants.

Keywords: Xanthones, Antioxidant capacity, ROS production

\footnotetext{
*Correspondence: veped@yahoo.com.mx; monica.atorres@gmail.com

'Departamento de Neuroquímica, Instituto Nacional de Neurología y

Neurocirugía Manuel Velasco Suárez, Insurgentes Sur 3877, S.S.A., México, DF

14269, México

Full list of author information is available at the end of the article
} 


\section{Background}

Redox homeostasis is maintained in organisms as an intracellular equilibrium between oxidant and antioxidant levels. An imbalance in favor of pro-oxidants results in oxidative stress which leads cells to damage through the alteration of endogenous macromolecules such as proteins, lipids and DNA [1,2]. Cells possess several antioxidant defense mechanisms designed to maintain homeostasis in response to oxidative stressors; however, under pathological conditions, such antioxidant defenses are depleted, thus eliciting oxidative damage. The most promising strategy to prevent the oxidative damage caused by reactive oxygen and nitrogen species (ROS/RNS) is the use of antioxidant molecules. These compounds can act either as direct antioxidant through free radical scavenging mechanisms or as indirect antioxidants by enhancing the antioxidant status toward both enzymatic and non-enzymatic systems. Different natural compounds have been described as antioxidants, as they are capable to decrease ROS levels in cells and are consequently useful to attenuate aging-related complications $[3,4]$ and for treatment of some human diseases, including atherosclerosis, cardiovascular diseases [5], inflammatory injury [6], cancer [7] and neurodegenerative diseases [8]. Natural antioxidants can therefore serve as innovative tools for preventive medicine. Calophyllum brasiliense Cambess is a big tree found in the tropical rain forests from Brazil to Mexico. It has been widely used in Latin American folk medicine to treat a variety of maladies including pain [9], inflammation, diabetes, hypertension [10,11], diarrhea, herpes and rheumatism [12]. Despite its extensive use, only a few biological activities have been reported in the scientific literature. Plants of this species are a rich source of xanthones and coumarins. Particularly, xanthones (9H-xanthen-9ones) are heterocyclic compounds with the dibenzo- $\gamma$ pyrone framework (Figure 1) [13]. Several xanthones have been isolated from Calophyllum brasiliense heartwood, including jacareubin (III) and 2-(3,3-dimethylallyl)-1,3,5,6tetrahydroxyxanthone (V). Xanthones from Callophyllum brasiliense Cambess have shown to be inhibitors of sulfotransferases, SULT1A1 and SULT2A1 [14], antibiotics [15], and inhibitors of gastric $\mathrm{H}^{+}, \mathrm{K}^{+}-\mathrm{ATPase}$ activity [16]. Furthermore, it has been reported that xanthones from other sources, like $\alpha$-mangostin, are effective antioxidants and could be important free radical scavengers [17-21]. This study was conducted to explore the scavenging effects and antioxidant properties of xanthones III and V (Figure $1 \mathrm{~b}$ and 1c, respectively) isolated from Callophylum brasiliensis, a species collected in the Mexican rain forest. Here, we evaluated the activities of these xanthones as scavengers of different ROS in synthetic systems. Also, we tested their effects against oxidative damage induced by $\mathrm{FeSO}_{4}$ in brain, liver and lung rat homogenates. a<smiles>CC1(C)C=Cc2c(cc3oc4c(O)c(O)ccc4c(=O)c3c2O)O1</smiles>

b<smiles>CC(C)=CCc1c(O)cc2oc3c(O)c(O)ccc3c(=O)c2c1O</smiles>

2-(3,3-dimethylallyl)-1,3,5,6-tetrahydroxyxanthone

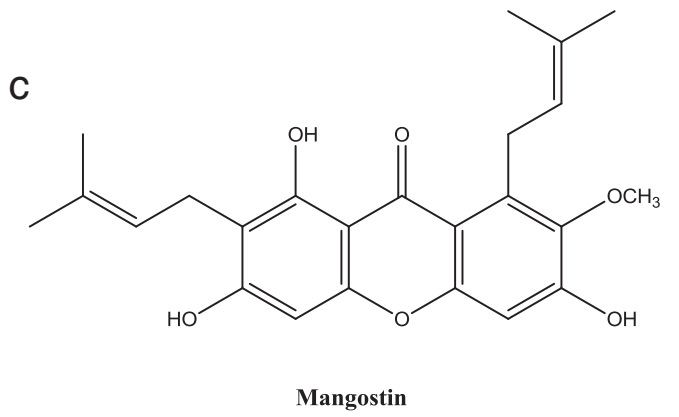

Figure 1 Chemical structures of xanthones: a) jacareubin (III), b) 2-(3,3-dimethylallyl)-1,3,5,6-tetrahydroxyxanthone (V), and c) a-mangostin.

\section{Methods}

Reagents

Calophyllum brasiliense Cambess (Clusiaceae) was collected by J.I. Calzada from the Selva Lancandona, Chiapas, México [22]. Identification was done by the collector, a voucher (JIC-3116), and wood simple (00011-XALw) are deposited in the Xal Herbarium, and Dr. Faustino Miranda Xylarium, both of the Instituto de Ecología, A.C., at Xalapa, Ver. México. Five xanthones (I-V) were isolated from Calophyllum brasiliense heartwood; xanthones III and $\mathrm{V}$ were obtained from a methanolic extract and were the most abundant constituents, as previously described, and identified by proton nuclear magnetic resonance and mass spectrometry [23]. $\alpha$-Mangostin was isolated from the dried pericarp of Garcinia mangostana, as previously described by Marquez-Valadez et al. [24].

$2^{\prime}, 7^{\prime}$-dichlorofluorescein (DCF), 2',7'-dichlorodihydrofluorescein diacetate (DCFH-DA), $\mathrm{FeSO}_{4}$, ascorbic acid, histidine, xylenol orange, ammonium iron (II) sulfate hexahydrate, 2,2' -azinobis-(3-ethylbenzothiazoline-6-sulfonic acid) (ABTS), 2,2-diphenyl-1-picrylhydrazyl (DPPH), bovine serum albumin (BSA), dimethylsulfoxide (DMSO), DL-penicillamine, 
glutathione $(\mathrm{GSH})$, nitroblue tetrazolium (NBT), phenazine methosulfate (PMS), ethylenediaminetetraacetic acid (EDTA), nicotinamide adenine dinucleotide (NADH), N-acetyl cysteine (NAC), N-2-hydroxyethyl-piperazine-N'-2-ethane sulphonic acid (HEPES), diethylenetriaminepentaacetic acid (DTPA), nicotinamide adenine dinucleotide reduced form (NADPH), Coomassie brilliant blue $\mathrm{R}$, mercaptoethanol, bromophenol blue, sodium dodecyl sulfate (SDS), sodium hypochlorite $(\mathrm{NaOCl})$, hydrogen peroxide $\left(\mathrm{H}_{2} \mathrm{O}_{2}\right)$ and N,N-dimethyl-4nitrosoaniline (DMNA) were all obtained from Sigma Aldrich Chemical Company (St. Louis, MO, USA). All other reagents were analytical grade and obtained from known commercial suppliers. Solutions were prepared using deionized water obtained from a Milli-RQ (Millipore) purifier system.

\section{Animals}

Tissue samples were obtained from the whole brain of male Wistar rats (280-320 g) from the vivarium of Facultad de Medicina (UNAM, Mexico City). A total of 40 rats were employed throughout the study. Before they were subjected to experimental treatments, animals were housed five per cage in acrylic cages and provided with standard commercial rat diet (Laboratory rodent diet 5001, PMI Feeds Inc., Richmond, IN, USA) and water ad libitum. Housing room was maintained under constant conditions of temperature $\left(25 \pm 3^{\circ} \mathrm{C}\right)$, humidity $(50 \pm 10 \%)$ and lighting (12 h light/dark cycles). Tissues were collected by decapitation and immediately dissected out on ice and preserved for limited times at $-70^{\circ} \mathrm{C}$. All procedures with animals were carried out according to the National Institutes of Health Guide for the Care and Use of Laboratory Animals and the local guidelines on the ethical use of animals from the Health Ministry of Mexico. During the dissections, all efforts were made to minimize animal suffering. The study was approved by Instituto Nacional de Neurología y Neurocirugía's ethics committee (30/12).

\section{Superoxide anion scavenging assessment}

Superoxide $\left(\mathrm{O}_{2}^{\bullet-}\right)$ scavenging was assessed according to previously reported methods [25] based on the reduction of NBT. The non-enzymatic PMS/NADH system generates superoxide radicals that reduce NBT into a purplecolored formazan. The reaction mixture contained HEPES buffer (20 mM, pH 7.4), $196 \mu \mathrm{M}$ NADH, $39.2 \mu \mathrm{M}$ NBT, $3.92 \mu \mathrm{M}$ PMS and increasing concentrations of Xanthone III or $\mathrm{V}(0-1,000 \mu \mathrm{M})$. Final mixture volume was $1.3 \mathrm{~mL}$. After incubation for $5 \mathrm{~min}$ at room temperature, the absorbance was taken at $560 \mathrm{~nm}$ against an appropriate blank solution. All tests were performed six times in an independent manner. Results are shown as percent of $\mathrm{O}_{2}^{\bullet-}$ scavenging capacity.

\section{Hydroxyl radical $\left(\mathrm{OH}^{\bullet}\right)$ scavenging assay}

The ability of xanthones III and V to scavenge $\mathrm{OH}^{\bullet}$ was estimated through the $\mathrm{Fe}^{3+}$-EDTA- $\mathrm{H}_{2} \mathrm{O}_{2}$-deoxyribose system [26,27]. The system contained different concentrations of xanthones III or V $(0-50 \mu \mathrm{M}$ or an equivalent volume of vehicle (ethanol, $0.025 \%$ final concentration used in the assay)) or distilled water for the control), $0.2 \mathrm{mM}$ ascorbic acid, $0.2 \mathrm{mM} \mathrm{FeCl}_{3}, 0.208 \mathrm{mM}$ EDTA, $1 \mathrm{mM} \mathrm{H}_{2} \mathrm{O}_{2}, 0.56 \mathrm{mM}$ deoxyribose, and $20 \mathrm{mM}$ phosphate buffer ( $\mathrm{pH}$ 7.4). $\mathrm{OH}^{\bullet}$ radicals were generated by incubating the mixture (final volume $1 \mathrm{~mL}$ ) at $37^{\circ} \mathrm{C}$ for $60 \mathrm{~min}$. The iron salt $\left(\mathrm{FeCl}_{3}\right)$ was mixed with EDTA before its addition to the reaction mixture. The extent of deoxyribose degradation by the formed $\mathrm{OH}^{\bullet}$ was measured directly in the aqueous phase by the thiobarbituric acid (TBA) test. Briefly, $100 \mu \mathrm{L}$ of the $0.05 \mathrm{M}$ TBA solution was added to the samples and final solutions were re-incubated in a boiling water bath $\left(94^{\circ} \mathrm{C}\right)$ for $10 \mathrm{~min}$. The optical density was estimated at a wavelength of $532 \mathrm{~nm}$ in a Genesys 8 spectrophotometer.

\section{Peroxynitrite $\left(\mathrm{ONOO}^{-}\right)$scavenging activity assessment} $\mathrm{ONOO}^{-}$was synthesized as previously described [28]. Briefly, $5 \mathrm{~mL}$ of an acidic solution $(0.6 \mathrm{M} \mathrm{HCl})$ of $\mathrm{H}_{2} \mathrm{O}_{2}$ $(0.7 \mathrm{M})$ was mixed with $5 \mathrm{~mL}$ of $0.6 \mathrm{M} \mathrm{KNO}_{2}$ on an ice bath for 1 second, and the reaction mixture was quenched with $5 \mathrm{~mL}$ of ice-cold 1.2 M NaOH . Residual $\mathrm{H}_{2} \mathrm{O}_{2}$ was removed using granular $\mathrm{MnO}_{2}$ prewashed with $1.2 \mathrm{M} \mathrm{NaOH}$, and this mixture was then left overnight at $-20^{\circ} \mathrm{C}$. The resulting yellow liquid layer on the top of the frozen mixture was collected for the experiment. Concentrations of $\mathrm{ONOO}^{-}$were determined before each experiment at $302 \mathrm{~nm}$ using a molar extinction coefficient of $1,670 \mathrm{M}^{-1} \mathrm{~cm}^{-1}$. ONOO ${ }^{-}$scavenging activity was measured by monitoring the oxidation of DCFH-DA to DCF by the modified method of Beckman and Crow [28,29]. The reaction mixture (in a final volume of $1.45 \mathrm{~mL}$ in $0.1 \mathrm{M}$ phosphate buffer $\mathrm{pH}$ 7.4) consisted of $14 \mu \mathrm{M}$ DTPA plus 36.2 $\mu$ M DCFH-DA plus the samples exposed to different xanthones III and $\mathrm{V}$ at increasing concentrations $(0-1,000 \mu \mathrm{M})$ and $35 \mu \mathrm{M} \mathrm{ONOO}^{-}$. The optical density was determined at $500 \mathrm{~nm}$ in a Genesys 8 spectrophotometer. A probe containing the reaction mixture, but not a sample, was considered as $0 \%$ scavenging capacity or $100 \%$ of DCFH-DA oxidation by the $\mathrm{ONOO}^{-}$added to the assay. To calculate the $\mathrm{ONOO}^{-}$scavenging ability, the readings of the tubes containing the xanthones or reference compounds were expressed as percentages of DCFH-DA oxidation and converted to percentages of scavenging ability, using as reference the tube with 100\% DCFHDA oxidation [26].

\section{$\mathrm{H}_{2} \mathrm{O}_{2}$ assay}

The ability of xanthones III or $\mathrm{V}$ to scavenge $\mathrm{H}_{2} \mathrm{O}_{2}$ was measured by the method described by Long et al. [30]. 
Briefly, 9 volumes of $4.4 \mathrm{mM}$ butylated hydroxytoluene in HPLC-grade methanol were mixed with 1 volume of $1 \mathrm{mM}$ xylenol orange and $2.56 \mathrm{mM}$ ammonium ferrous sulfate in $0.25 \mathrm{M} \mathrm{H}_{2} \mathrm{SO}_{4}$ to give the "working" FOX reagent. A solution of $75 \mu \mathrm{M} \mathrm{H}_{2} \mathrm{O}_{2}$ was mixed with different concentrations of xanthones III and V $(0-1000 \mu \mathrm{M})$ and added with $0.01 \mathrm{~mL}$ of HPLC-grade methanol, immediately followed by the addition of $0.9 \mathrm{~mL}$ of FOX reagent, vortexed for 5 seconds, and then incubated at room temperature for $30 \mathrm{~min}$ (final volume $1.3 \mathrm{~mL}$ ). Tubes were centrifuged at $15,000 \times \mathrm{g}$ for $10 \mathrm{~min}$ and $\mathrm{ab}-$ sorbance was read at $560 \mathrm{~nm}$ against a methanol blank.

\section{$\mathrm{OH}^{\bullet}$-mediated protein degradation}

Experiments for detection of $\mathrm{OH}^{\bullet}$-mediated BSA oxidation were carried out using a metal-catalyzed reaction based on the method described by Kocha et al. [31] with modifications. A solution of ascorbic acid (1.6 mM)/ EDTA $(0.8 \mathrm{mM}) /\left(\mathrm{NH}_{4}\right)_{2} \mathrm{Fe}\left(\mathrm{SO}_{4}\right)_{2}(0.8 \mathrm{mM})$ was prepared in $50 \mathrm{mM}$ phosphate buffer (pH 7.4). Briefly, 1\% BSA and $250 \mu \mathrm{L}$ of the ascorbic acid/EDTA/ $\left(\mathrm{NH}_{4}\right)_{2} \mathrm{Fe}\left(\mathrm{SO}_{4}\right)_{2} \cdot 6 \mathrm{H}_{2} \mathrm{O}$ solution were mixed in the presence or absence of xanthones III and V or $\alpha$-mangostin $(0.5,1$ and $2.5 \mu \mathrm{M})$. The generation of $\mathrm{OH}^{\bullet}$ was initiated through the addition of $15 \mu \mathrm{L}$ of $2 \% \mathrm{H}_{2} \mathrm{O}_{2}$. In control tubes (without the $\mathrm{OH}^{\bullet}$ generator system), $\mathrm{H}_{2} \mathrm{O}_{2}$ was replaced by water. The final volume for all probes was $250 \mu \mathrm{L}$. The maximum concentration of $\mathrm{EtOH}$ (vehicle) in reaction tube was $0.01 \%$. After $1 \mathrm{~h}$ of incubation at room temperature, $250 \mu \mathrm{L}$ of $20 \%$ trichloroacetic acid was added, and the mixture was then centrifuged at 2,236 $\mathrm{xg}$ for $30 \mathrm{~min}$ at $4^{\circ} \mathrm{C}$. The supernatants were discarded and the pellets were resuspended in $500 \mu \mathrm{L}$ of $0.1 \mathrm{M} \mathrm{NaOH}$. To evaluate the oxidative damage to proteins induced by $\mathrm{OH}^{\bullet}$, the samples were subjected to SDS-polyacrilamide gel electrophoresis. BSA (50 $\mu \mathrm{g}$; from resuspended pellets) was mixed (1:1) with loading buffer (10\% glycerol, 2\% SDS, 25 mM Tris-HCl (pH 6.8), $5 \%$ mercaptoethanol, $0.1 \%$ bromophenol blue) and heated at $100^{\circ} \mathrm{C}$ for $1 \mathrm{~min}$. The protein sample (40 $\mu \mathrm{g}$ per well) was loaded in a $12 \%$ polyacrylamide gel and the electrophoresis was run at $150 \mathrm{~V}$ for $1 \mathrm{~h}$. After running out, gels were stained with $0.2 \%$ Coomassie brilliant blue $\mathrm{R}$ for $1 \mathrm{~h}$. Images were visualized and captured in a BioRad Gel Documentation System (Gel Doc 1000 BioRad). Protein levels were densitometrically evaluated using the Quantity One Program 4.2 [32].

\section{$\mathrm{OH}^{\bullet}$-mediated DNA degradation}

DNA samples were obtained from mice tails and incubated overnight at $55^{\circ} \mathrm{C}$ in lysis buffer (Tris $100 \mathrm{mM}$, $\mathrm{pH}$ 8.5, $5 \mathrm{mM}$ EDTA, $0.2 \%$ SDS, $200 \mathrm{mM} \mathrm{NaCl}$ and $100 \mu \mathrm{g} / \mathrm{ml}$ proteinase $\mathrm{K})$. The mixtures were deproteinized with phenol:chlorophorm:isoamilic ethanol (25:24:1). The DNA in the recovered supernatant was precipitated by adding cold isopropanol and washed with $70 \%$ ethanol solution, then dissolved in endonucleases-free water for the assay. Experiments for detection of $\mathrm{OH}^{\bullet}$-mediated DNA oxidation were carried out by using a metal-catalyzed reaction based on Kocha et al. [31] with modifications. A solution of ascorbic acid $(1.6 \mathrm{mM}) /$ EDTA $(0.8 \mathrm{mM}) /\left(\mathrm{NH}_{4}\right)$ ${ }_{2} \mathrm{Fe}\left(\mathrm{SO}_{4}\right)_{2}(0.8 \mathrm{mM})$ was prepared in $20 \mathrm{mM}$ phosphate buffer (pH 7.4) plus DNA, xanthones III or xanthone V, and $\alpha$-mangostin $(0.5,1$ and $2.5 \mu \mathrm{M})$. Briefly, $20 \mu \mathrm{g}$ of purified DNA was mixed with $25 \mu \mathrm{L}$ of the ascorbic acid/ EDTA/ $\left(\mathrm{NH}_{4}\right) 2 \mathrm{Fe}\left(\mathrm{SO}_{4}\right)_{2} \cdot 6 \mathrm{H}_{2} \mathrm{O}$ solution, in presence or absence of xanthones and $\alpha$-mangostin. The generation of $\mathrm{OH}^{\bullet}$ was initiated through the addition of $15 \mu \mathrm{l}$ of $2 \%$ $\mathrm{H}_{2} \mathrm{O}_{2}$. In control tubes (without the $\mathrm{OH}^{\bullet}$ generator system), $\mathrm{H}_{2} \mathrm{O}_{2}$ was replaced by water. The final volume for all probes was $250 \mu \mathrm{L}$. The maximum concentration of $\mathrm{EtOH}$ (vehicle) in reaction tube was $0.01 \%$. After $15 \mathrm{~min}$ of incubation at room temperature, $50 \mu \mathrm{L}$ of loading buffer was added to stop the reaction. To evaluate the oxidative damage to DNA induced by $\mathrm{OH}^{\bullet}, 10 \mu \mathrm{L}$ of the samples were subjected to agarose (2\%) gel electrophoresis for $20 \mathrm{~min}$ at $90 \mathrm{~V}$. After running out, gels were stained with ethidium bromide $(0.1 \mathrm{mg} / \mathrm{ml})$. Images were visualized and captured in a BioRad Gel Documentation System (Gel Doc 1000 BioRad). In order to estimate DNA degradation; the main DNA band per well was densitometrically evaluated using the Quantity One Program 4.2 [32].

\section{Assay of lipid peroxidation}

Lipid peroxidation (LP) was assessed in homogenates of different tissues (brain, liver and kidney) by estimation of TBA-reactive substances (TBA-RS), according to a previous report [33]. Each tissue was homogenized (brain 1:10, liver 1:300, kidney 1:100 w/v) in Krebs buffer ( $\mathrm{pH} 7.4$ ) containing $19 \mathrm{mM} \mathrm{NaCl}, 5 \mathrm{mM} \mathrm{KCl}, 2 \mathrm{mM} \mathrm{CaCl}_{2}$, $1.2 \mathrm{mM} \mathrm{MgSO}_{4}, 5 \mathrm{mM}$ glucose, $13 \mathrm{mM} \mathrm{NaH}_{2} \mathrm{PO}_{4}$ and $3 \mathrm{mM} \mathrm{Na}_{2} \mathrm{HPO}_{4}$. Aliquots of $250 \mu \mathrm{L}$ of the homogenate were incubated in the presence of $\mathrm{FeSO}_{4}(5 \mu \mathrm{M})$ and/or xanthone III and V $(0.5,1$ and $2.5 \mu \mathrm{M})$. The final volume for all probes was $500 \mu \mathrm{L}$. All incubations were done at $37^{\circ} \mathrm{C}$ for $2 \mathrm{~h}$ in a shaking water bath. At the end of the incubation time, $500 \mu \mathrm{L}$ of the TBA reagent (containing $0.75 \mathrm{~g}$ of $\mathrm{TBA}+15 \mathrm{~g}$ of trichloroacetic acid $+2.54 \mathrm{~mL}$ of $\mathrm{HCl}$ ) were added and final solutions were re-incubated in a boiling water bath $\left(94^{\circ} \mathrm{C}\right)$ for additional $20 \mathrm{~min}$. Samples were then kept on ice for $5 \mathrm{~min}$ and centrifuged at 3,000 $\mathrm{xg}$ for $15 \mathrm{~min}$. The optical density of supernatants was estimated at a wavelength of $532 \mathrm{~nm}$ in a Genesys 8 spectrophotometer. Concentrations of malondialdehyde (MDA) were calculated by interpolation in a standard curve of MDA, constructed in parallel. Results were expressed as percent of LP vs. control. 


\section{Determination of ROS in homogenates}

ROS were detected by DCF fluorescence [34,35]. Aliquots $(500 \mu \mathrm{L})$ of the homogenates (brain, liver and kidney) were incubated in the absence (control) or presence of $5 \mu \mathrm{M} \mathrm{FeSO}_{4}$ and/or xanthones III or $\mathrm{V}(0.5,1$ and $2.5 \mu \mathrm{M})$ at $37^{\circ} \mathrm{C}$ in a shaking-water bath for $2 \mathrm{~h}$. The final volume for all probes was $1 \mathrm{~mL}$. Then $100 \mu \mathrm{L}$ of $75 \mu \mathrm{M}$ DCF were added to samples and incubated for $30 \mathrm{~min}$ in the abscence of light. Finally, samples were centrifuged at $6,000 \mathrm{x} g$ for $15 \mathrm{~min}$. ROS were conventionally detected in supernatants by fluorescent spectrometry in a Perkin-Elmer LS50 spectrometer at $488 \mathrm{~nm}$ (excitation wavelength) and $532 \mathrm{~nm}$ (emission wavelength). Results were expressed as percent of ROS formation vs. control.

\section{Glutathione reductase (GR) activity}

GR activity in forebrain, liver and kidney homogenates was assayed using oxidized glutathione (GSSG) as substrate and measuring the consumption of NADPH at $340 \mathrm{~nm}$ [36]. Briefly, aliquots of $250 \mu \mathrm{L}$ of the homogenate were incubated in the presence of $5 \mu \mathrm{M} \mathrm{FeSO}_{4}$ and/or xanthone III and $\mathrm{V}(0.5,1$ and $2.5 \mu \mathrm{M})$. The final volume for all probes was $500 \mu \mathrm{L}$. All incubations were done at $37^{\circ} \mathrm{C}$ for $2 \mathrm{~h}$ in a shaking water bath. After incubation $50 \mu \mathrm{L}$ of homogenate were mixed with $950 \mu \mathrm{L}$ of the reaction mixture $(1.25 \mathrm{mM}$ GSSG, $0.1 \mathrm{mM}$ NADPH, $0.5 \mathrm{mM} \mathrm{Na} \mathrm{F}_{2}$ EDTA in $100 \mathrm{mM}$ phosphate buffer, pH 7.6). One unit of GR was defined as the amount of enzyme that oxidizes $1 \mu \mathrm{mol} \mathrm{NADPH} / \mathrm{min}$. Data were obtained as units per milligram of protein and expressed as percent of GR activity vs. control.

\section{Statistical analysis}

Results were expressed as mean values \pm S.E.M. ROS scavenging capacity was expressed as $50 \%$ of the inhibitory concentration $\left(\mathrm{IC}_{50}\right)$ value, which denotes the concentration of the xanthone and standard $(\mu \mathrm{M})$ required to reach a $50 \%$ reduction in the respective molecule oxidation relative to the probe without xanthones or reference compound. $\mathrm{IC}_{50}$ was calculated by the least square method. The lower the $\mathrm{IC}_{50}$ value the higher the scavenging capacity of the compound. In regard to the experiments carried out in tissue homogenates, $\mathrm{n}=6$ experiments (each experiment corresponding to one rat) were considered. All data were analyzed by one-way ANOVA followed by Tukey's test for multiple comparisons, using the Prism 3.02 software (GraphPad, San Diego, CA, USA). Values of $\mathrm{P}<0.05$ were considered as statistically significant.

\section{Results}

\section{Scavenging activities of xanthones III and V}

Xanthones III and $\mathrm{V}$ were able to scavenge $\mathrm{O}_{2}^{*-}$ (Figure 2A), $\mathrm{OH}^{\bullet}$ (Figure 2B) and $\mathrm{ONOO}^{-}$(Figure 2C) in a concentration-dependent manner, in contrast, they were unable to scavenge $\mathrm{H}_{2} \mathrm{O}_{2}$ (data not shown). The $\mathrm{IC}_{50}$ values, calculated from the linear portion of the dose-response curve, are shown in Table 1. All these values are in the $\mu \mathrm{M}$ range. Xanthone $\mathrm{V}$ was more effective to scavenge ROS than xanthone III.

\section{Xanthones III and V prevent the oxidative protein degradation in a concentration-dependent manner}

Xanthones III and V (0.5, 1 and $2.5 \mu \mathrm{M}$; Figure 3) were able to prevent, in a concentration-dependent manner, the BSA degradation induced by $\mathrm{OH}^{\bullet}$. A densitometric assessment was employed for protein detection. Protection was found since the lowest concentration of each xanthone used $(0.5 \mu \mathrm{M})$, although this protection was more evident at higher concentrations ( 1 and $2.5 \mu \mathrm{M}$; Figures $3 \mathrm{a}$ and $3 \mathrm{~b}$ ). The EtOH did not have effect in the DNA degradation induced by $\mathrm{OH}^{\bullet}$ (Figure 4c; line 3). These data confirm previous observations on the $\mathrm{OH}^{\bullet}$-scavenging capacity of xanthones. $\alpha$-Mangostin prevented BSA degradation induced by $\mathrm{OH}^{\bullet}$ at all concentrations used.

Xanthones III and V block DNA degradation induced by $\mathrm{OH}$. Figure 4a shows the protective effect of xanthones III (lanes 7-9) and V (lanes 10-12) on DNA degradation induced by $\mathrm{OH}^{\bullet}$ (lane 6). The effect of $\alpha$-mangostin was also evaluated in this paradigm (lanes 13-15), as a reference. The $\mathrm{OH}^{\bullet}$ generator system induced around 35\% of DNA degradation (Figure 4b), which was completely abolished by xanthones III and V and $\alpha$-mangostin, an effect not dependent of the concentration used. Figure 4c shows that the three compounds tested did not exert any effect when compared to control group at the highest concentration used $(2.5 \mu \mathrm{M}$; lanes 3,4 and 5$)$ and also shows that the $\mathrm{EtOH}$ at the maximum concentration used $(0.01 \%)$ does not have any effect on the DNA degradation induced by $\mathrm{OH}^{*}$ (line 11).

\section{Xanthones III and $\mathrm{V}$ reduce the ROS production induced by $\mathrm{FeSO}_{4}$}

$\mathrm{FeSO}_{4}$ induced an increase in ROS formation in forebrain, liver and kidney (186.7\% 380\%, and 380.3\% when compared to control group, respectively (Figures 5 and $6 a, 5$ and $6 b$ and 5 and $6 c$ ). In all preparations, xanthones III and V $(0.5,1$ and $2.5 \mu \mathrm{M}$; Figures 5 and 6 , respectively) reduced ROS formation to basal levels and also decreased ROS formation in a concentrationdependent manner in the homogenates exposed to the ferrous iron. Upon these conditions, ethanol (used as vehicle) did not have any effect when compared to control group. Both xanthones showed the same effectiveness to decrease this marker.

\section{Xanthones III and $\mathrm{V}$ reduced the lipid peroxidation produced by $\mathrm{FeSO}_{4}$}

Figures 7 and 8 show the $\mathrm{FeSO}_{4}$-induced increase in LP in homogenates of (a) forebrain, (b) liver and (c) 

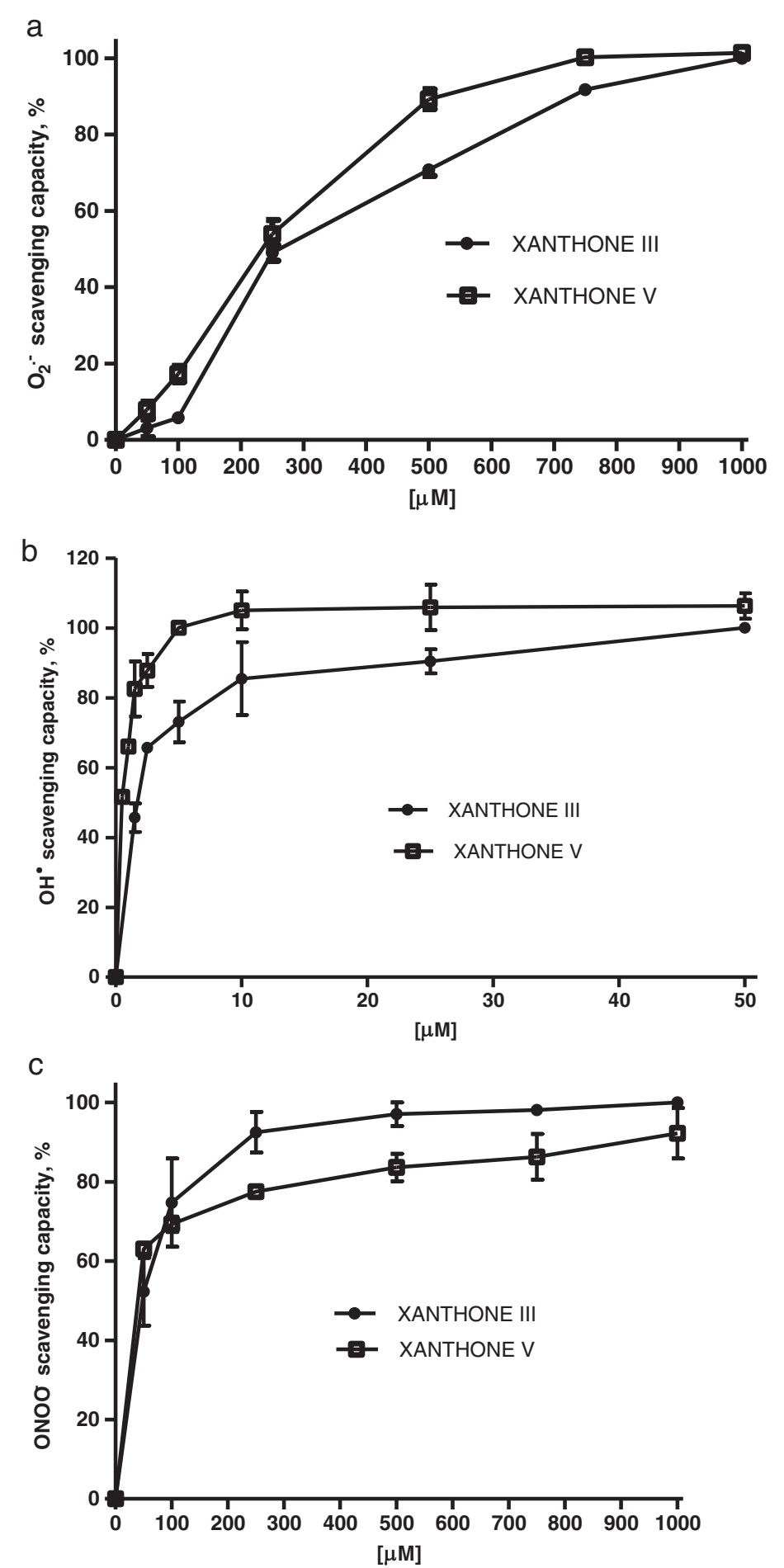

Figure 2 Xanthones III and $\mathrm{V}$ are able to scavenge (a) $\mathrm{O}_{2}^{--}$, (b) $\mathrm{OH}^{\bullet}$ and (c) $\mathrm{ONOO}^{-}$in a concentration-dependent manner. In vitro systems of ROS production were assessed and subjected to different concentrations of xanthones $(0.5-1,000 \mu \mathrm{M})$. Both xanthones showed an effective capacity as scavengers of $\mathrm{O}_{2}^{-}, \mathrm{OH}^{\bullet}$ and $\mathrm{ONOO}^{-}$. Data are presented as mean values \pm S.E.M. of seven experiments per group.

kidney $(217.5 \%, 383 \%$ and $418.3 \%$ when compared to control group, respectively). Xanthones III and V decreased the $\mathrm{FeSO}_{4}$-induced LP in a concentrationdependent manner in all tissue homogenates tested
(Figures 7 and 8 , respectively). In addition, the incubation with vehicle alone did not exert any effect on this marker. However, both xanthones III and V reduced lipid peroxidation at the highest concentration 
Table 1 ROS scavenging ability of xanthones III and V

\begin{tabular}{lccc}
\hline & $\mathbf{O}_{\mathbf{2}}^{--}$ & $\mathbf{O H}^{\bullet}$ & ONOO $^{-}$ \\
\hline Xanthone III & $336.5 \pm 8.9$ & $1.82 \pm 0.06$ & $63.6 \pm 11.6$ \\
Xanthone V & $262.4 \pm 7.7$ & $0.07 \pm 0.003$ & $29.6 \pm 6.8$
\end{tabular}

Values are expressed as $\mathrm{IC}_{50}(\mu \mathrm{M})$.

Data are mean \pm S.E.M. of six experiments per group. $\mathrm{OH}^{\bullet}$ : hydroxyl radicals,

$\mathrm{O}_{2}^{\bullet-}$ : superoxide anion, $\mathrm{ONOO}^{-}$: peroxynitrite anion. tested $(2.5 \mu \mathrm{M})$ when compared to control group in forebrain and liver homogenates.

\section{Xanthone III and V prevent the reduction of glutathione} reductase activity induced by $\mathrm{FeSO}_{4}$

In brain homogenates, xanthones III and $\mathrm{V}$ prevented the decrease in GR activity generated by $\mathrm{FeSO}_{4}(\sim 50 \%$ of reduction when compared to control group; Figure 9). In liver and kidney homogenates, ferrous iron did not

a

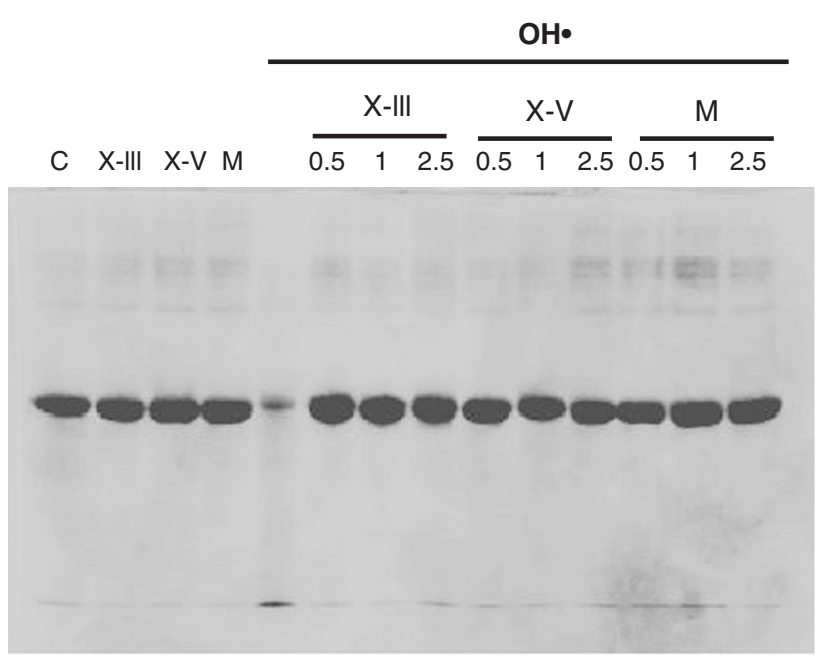

b

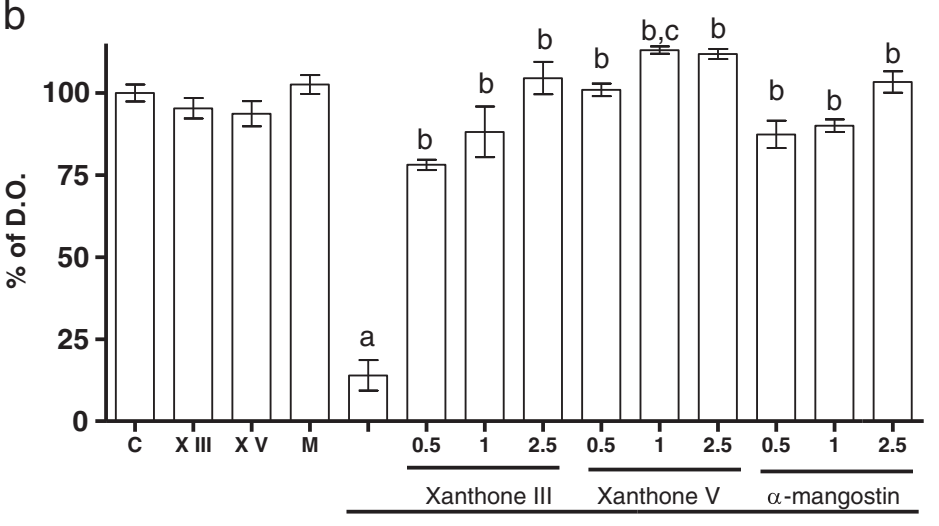

C

$\mathrm{OH}^{\circ}$

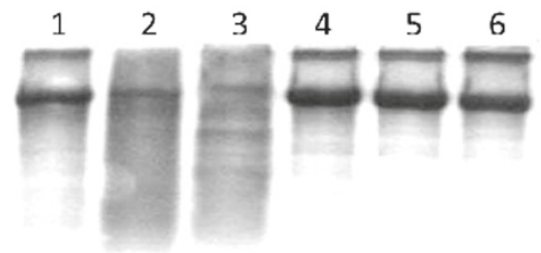

Figure 3 Protective effect of xanthones III and V on bovine serum albumin (BSA) oxidation induced by an $\mathrm{OH}^{\bullet}$ generation system. a) Representative Coomassie blue-stained-BSA gel is shown. Different concentrations $(0.5,1$ and $2.5 \mu \mathrm{M})$ of xanthones III (X-III) and V $(X-V)$ and amangostin (M) were tested in $\mathrm{OH}^{\bullet}$ generator system. b) Quantitative representation of the BSA detection. c) Representative Coomassie bluestained-BSA gel is shown. Lane 1, BSA; lane 2, $\mathrm{OH}^{\bullet}+\mathrm{BSA}$; lane 3, EtOH (0.01\%) + BSA + $\mathrm{OH}^{\bullet}$; lanes 4, 5 and 6, xanthones III, $\mathrm{V}$ and a-mangostin $(2.5 \mu \mathrm{M})$ respectively. $+\mathrm{BSA}+\mathrm{OH}^{\bullet}$. Data are presented as mean \pm S.E.M. of 4 independent experiments. ${ }^{a} \mathrm{P}<0.01$ vs. Control (C), ${ }^{\mathrm{b}} \mathrm{P}<0.01 \mathrm{vs}$. BSA + $\mathrm{OH}^{\bullet},{ }^{\mathrm{C}} \mathrm{P}<0.01$ vs. a-mangostin. 
a

$\begin{array}{lllllllllllllll}1 & 2 & 3 & 4 & 5 & 6 & 7 & 8 & 9 & 10 & 11 & 12 & 13 & 14 & 15\end{array}$

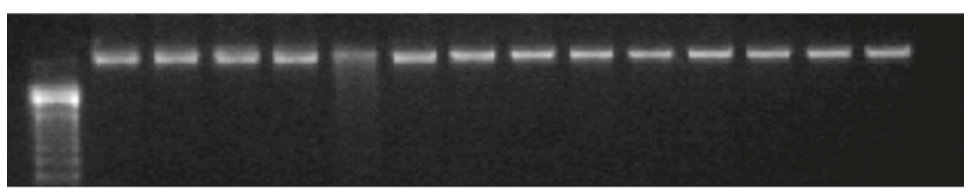

b

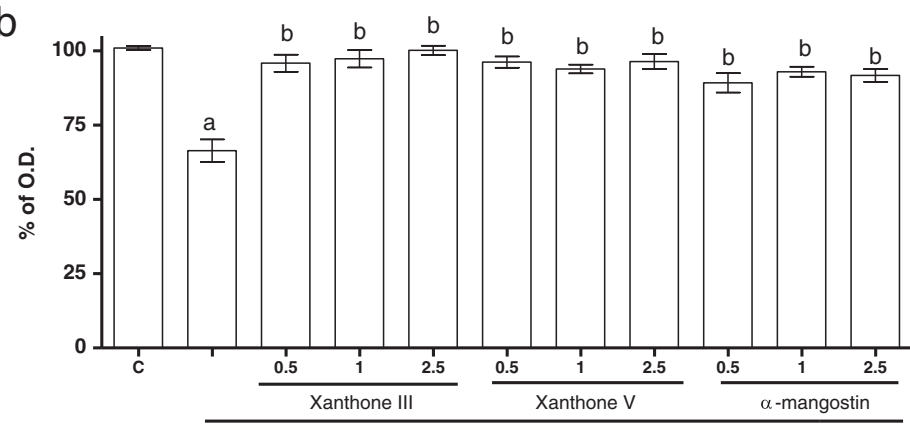

C

$\mathrm{OH} \bullet$

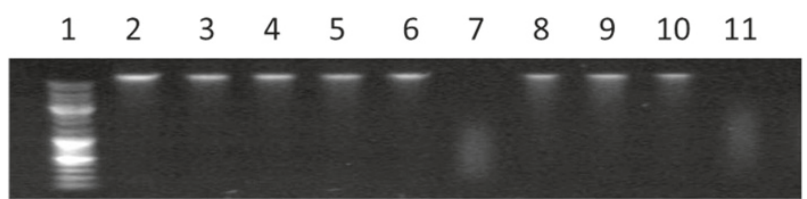

Figure 4 Xanthones exerted a protective effect on DNA oxidation induced by an $\mathrm{OH}^{\bullet}$ generation system. a) Representative ethidium bromide stained DNA-agarose gel. Lane 1, molecular weight markers; lane 2, DNA (20 $\mu \mathrm{g})$; lane 3, xanthone III $(2.5 \mu \mathrm{M})$; lane 4, xanthone V $(2.5 \mu \mathrm{M})$; lane 5, a-mangostin $(2.5 \mu \mathrm{M})$; lane 6, DNA $(20 \mu \mathrm{g})+\mathrm{OH}^{\bullet}$; lanes 7-9 DNA $(20 \mu \mathrm{g})+\mathrm{OH}^{\bullet}+$ xanthone III $(0.5,1$ and $2.5 \mu \mathrm{M}$, respectively); lane 10-12 DNA $(20 \mu \mathrm{g})+\mathrm{OH}^{\bullet}+$ xanthone $\mathrm{V}(0.5,1$ and $2.5 \mu \mathrm{M}$, respectively); lanes 13-15, DNA (20 $\mu \mathrm{g})+\mathrm{OH}^{\bullet}+\mathrm{a}$-mangostin $(0.5,1$ and $2.5 \mu \mathrm{M}$, respectively). b) Quantitative representation of the DNA detection. c) Representative ethidium bromide stained DNA-agarose gel. Lane 1, molecular weight markers; lane 2, DNA (20 $\mu \mathrm{g})$; lane 3, xanthone III $(2.5 \mu \mathrm{M})$; lane 4, xanthone V (2.5 $\mu \mathrm{M})$; lane 5, a-mangostin $(2.5 \mu \mathrm{M})$; lane 6, EtOH; lanes 7, DNA $(20 \mu \mathrm{g})+\mathrm{OH}^{\bullet}$; lane 8, DNA $(20 \mu \mathrm{g})+\mathrm{OH}^{\bullet}+$ xanthone III $(2.5 \mu \mathrm{M})$; lane 9, DNA $(20 \mu \mathrm{g})+\mathrm{OH}^{\bullet}+$ xanthone V $(2.5 \mu \mathrm{M})$; lanes 10 , DNA $(20 \mu \mathrm{g})+\mathrm{OH}^{\bullet}+\mathrm{a}$-mangostin $(2.5 \mu \mathrm{M})$ and lane 11, DNA $(20 \mu \mathrm{g})+\mathrm{OH}^{\bullet}+\mathrm{EtOH}$. Data are presented as mean \pm S.E.M of 4 independent experiments. ${ }^{a} \mathrm{P}<0.01$ vs. Control, ${ }^{b} \mathrm{P}<0.01$ vs. $\mathrm{DNA}+\mathrm{OH}^{\bullet}$.

have any effect in GR activity (data not shown). The vehicle alone showed no effects.

\section{Discussion}

Several properties have been described for compounds derived from Calophyllum brasiliense Cambess $[9,10,16]$. Specially, xanthones exhibit diverse biological properties, including antihypertensive, antioxidative, antithrombotic and anticancer activities [37,38]. The xanthone nucleus is known as 9-xanthenone or dibenzo- $\gamma$-pyrone [39-41] and its biological activity depends on specific substituents and their positions to the basic structure in the ring system of each molecule [37]. The xanthones used here, III and V, are the most abundant extracted from the heartwood of C. brasiliense. In the present study, novel findings on ROS scavenging activity and protective effects were described for the antioxidant compounds xanthones III and V. Here, we found that both xanthones were able to scavenge $\mathrm{O}_{2}^{\bullet-}, \mathrm{OH}^{\bullet}$ and $\mathrm{ONOO}^{-}$; under our assay conditions. It has been reported that glutathione show a higher $\mathrm{IC}_{50}$ for superoxide $(2,171.5 \mu \mathrm{M})$ than the both xanthones employed in this work [42], and also we demonstrated that these xanthones are better $\mathrm{OH}^{*}-$ scavenger than $\alpha$-mangostin $\left(\mathrm{IC}_{50}: 8000 \mu \mathrm{M}\right)[19,43]$. Noteworthy, xanthone $\mathrm{V}$ showed a lower $\mathrm{IC}_{50}$ than xanthone III in all the synthetic scavenging assays. This effect could be due to the fact that xanthone $\mathrm{V}$ has an extra hydroxyl group in C-3 compared to xanthone III. Several authors have reported that the presence of hydroxyl groups is an important factor for their functionality $[16,44,45]$. The scavenging capacity of these xanthones is notorious since it has been widely reported that excessive amounts of ROS can affect, in a direct or indirect manner, some essential biomolecules such as DNA, proteins and lipids, further leading to cell death either through necrosis or apoptosis [46]. Also, this scavenging capacity supports 

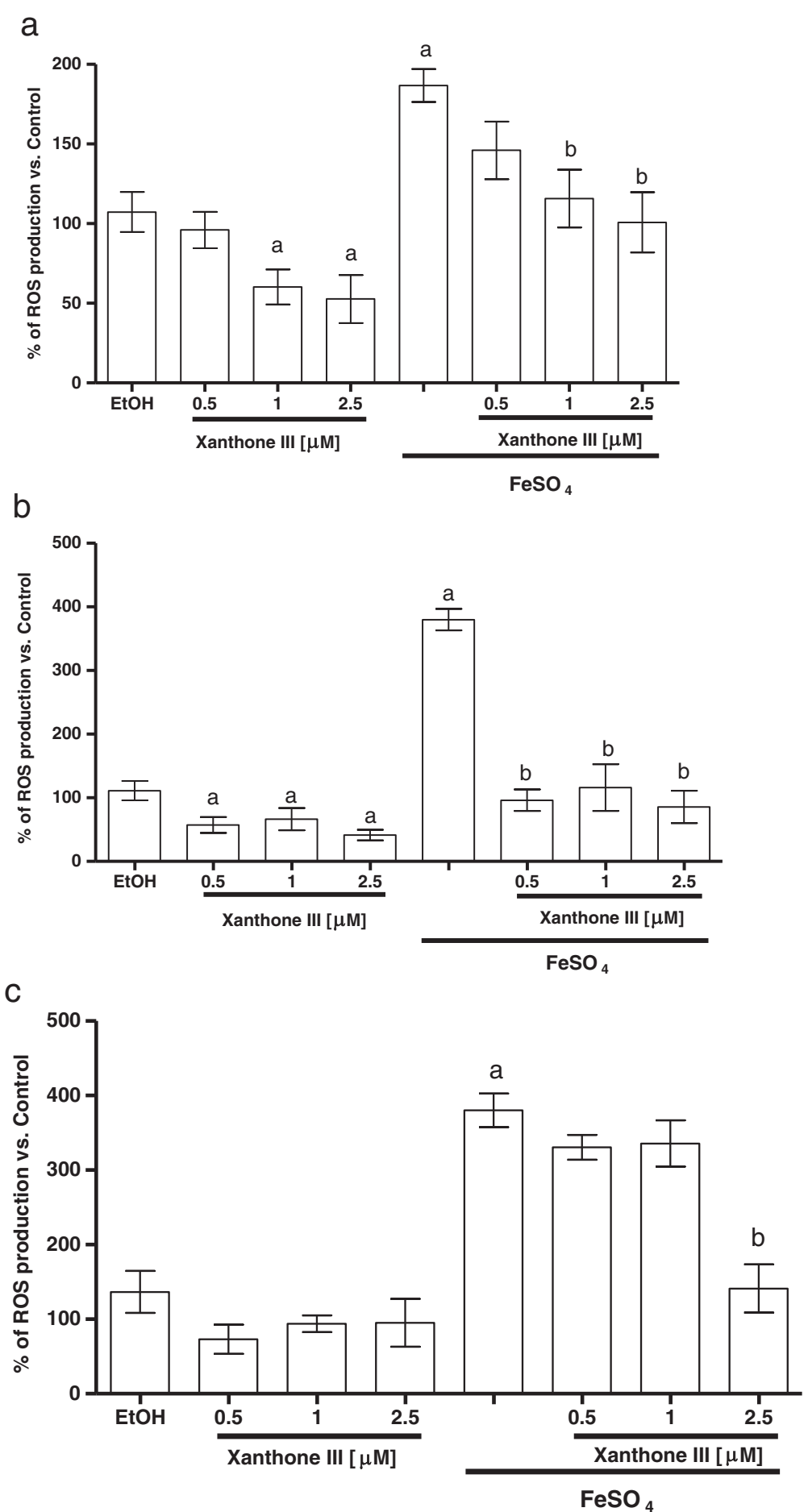

Figure 5 Effect of xanthone III on the ROS production induced by $\mathrm{FeSO}_{4}$ in homogenates of different tissues. a) Forebrain, b) liver and c) kidney homogenates were incubated with $5 \mathrm{MM} \mathrm{FeSO}_{4}$ and different concentrations on xanthone III $(0-2.5 \mu \mathrm{M})$ in Kreb's buffer. Control is represented by $100 \%$ and $\mathrm{EtOH}(50 \%)$ was used as a vehicle to dissolve xanthones. In all panels, mean values \pm S.E.M. of six experiments per group are shown. ${ }^{\mathrm{a}} \mathrm{P}<0.01$ vs. control; ${ }^{\mathrm{b}} \mathrm{P}<0.01$ vs. $\mathrm{FeSO}_{4}$.

the previous hypothesis postulated by Reyes-Chilpa [23], in which he proposed that xanthones III and V prevent the wood degradation by brown rot fungi that involves secretion of fungal $\mathrm{H}_{2} \mathrm{O}_{2}$ and its interactions with wood $\mathrm{Fe}^{2+}$ ions through their antioxidant and free radical scavenging properties. 


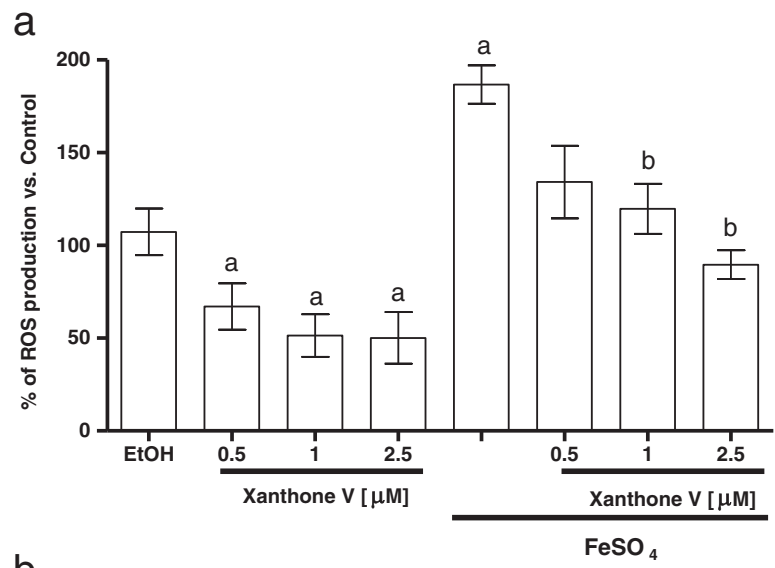

b

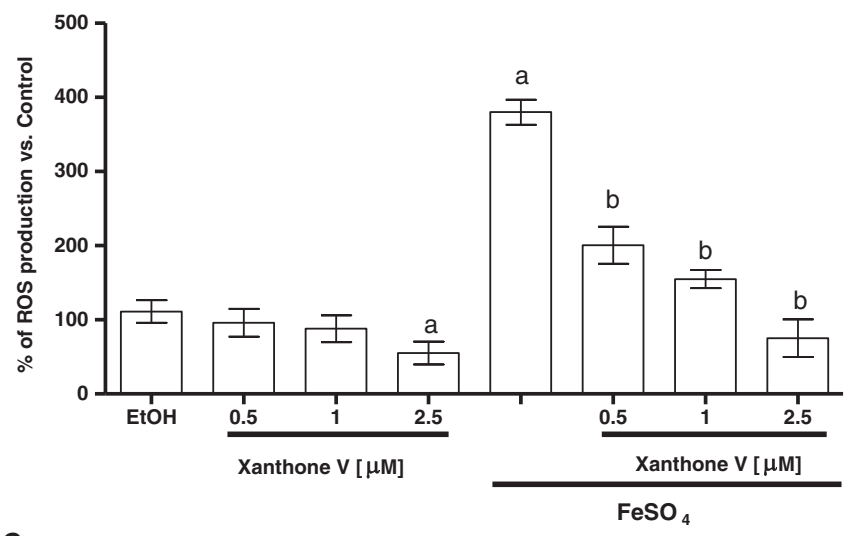

C

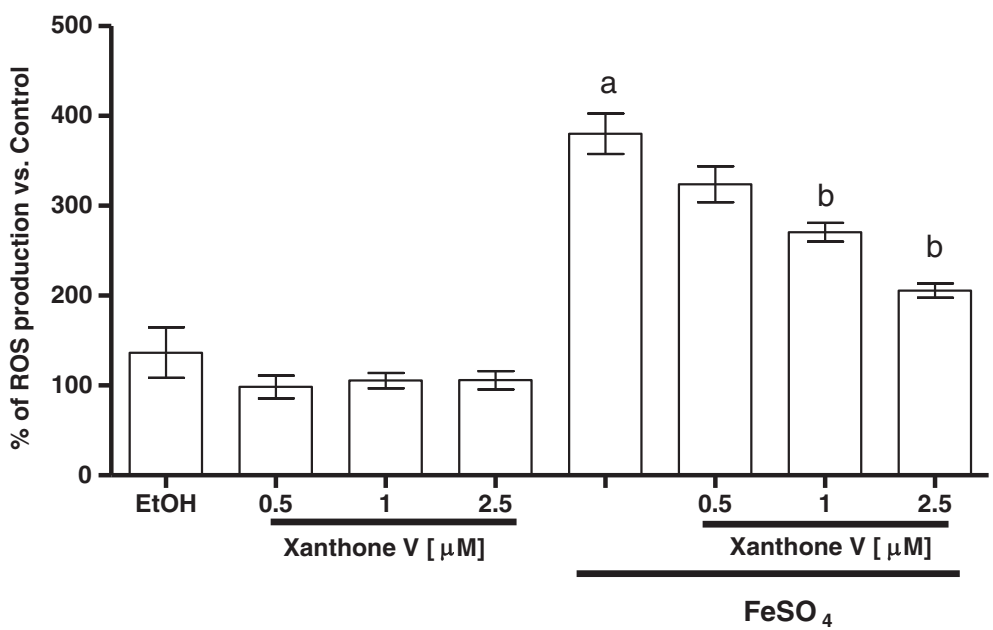

Figure 6 Effect of xanthone $\mathbf{V}$ on the ROS production induced by $\mathrm{FeSO}_{4}$ in homogenates of different tissues. a) Forebrain, b) liver and c) kidney homogenates were incubated with $5 \mathrm{MM} \mathrm{FeSO}_{4}$ and different concentrations on xanthone $\mathrm{V}(0-2.5 \mu \mathrm{M})$ in Kreb's buffer. Control is represented by $100 \%$. In all panels, mean values \pm S.E.M. of six experiments per group are shown. ${ }^{a} \mathrm{P}<0.01 \mathrm{vs}$. control; ${ }^{\mathrm{b}} \mathrm{P}<0.01 \mathrm{vs}$. $\mathrm{FeSO}_{4}$.

We also showed that BSA and DNA degradation were prevented by both xanthones III and V, exhibiting the same efficacy than $\alpha$-mangostin to prevent these changes. The degradation of BSA and DNA was promoted by the Fenton reaction, supporting the concept that plasma concentrations of transition metals such as copper or iron, can increase with age as well as in some pathologies such as diabetes. These metals readily catalyze reactions related to the formation of $\mathrm{H}_{2} \mathrm{O}_{2}$ through the Fenton reaction to form $\mathrm{OH}^{\bullet}$, the most powerful oxidizing species able to interact directly with DNA and proteins. 

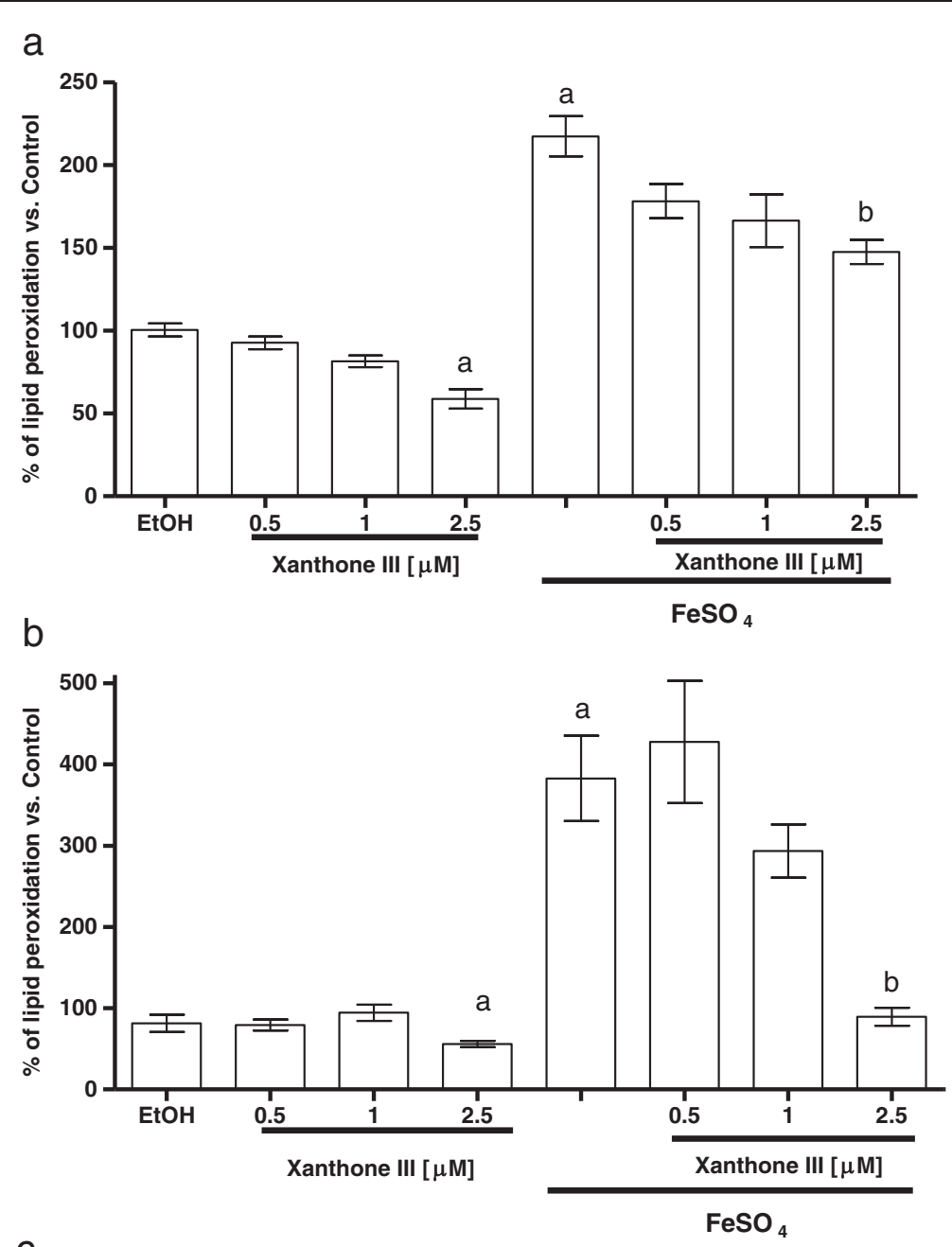

C

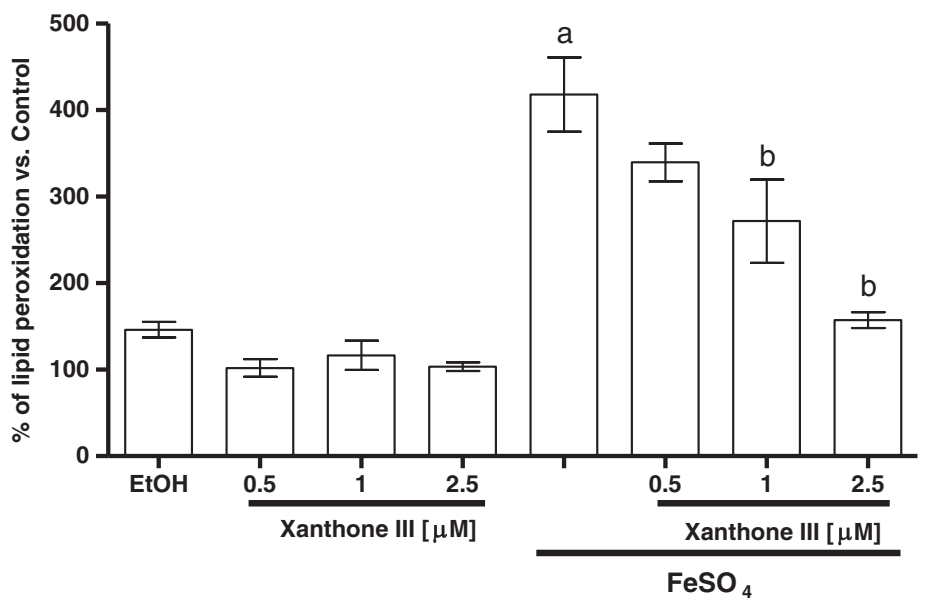

Figure 7 Xanthone III decreased lipid peroxidation (LP) induce by $\mathrm{FeSO}_{4}$. Different concentrations of xanthone III $(0.5,1,2.5 \mu \mathrm{M})$ were incubated in the presence of ferrous iron in a) forebrain, b) liver and c) kidney homogenates. Control is represented by $100 \%$. Data are presented as mean values \pm S.E.M. of six experiments per group. ${ }^{a} \mathrm{P}<0.01$ control; ${ }^{\mathrm{b}} \mathrm{P}<0.01 \mathrm{vs}$. $\mathrm{FeSO}_{4}$.

Due to the scavenging capacity exerted by xanthones III and V, the potential protective effect of these molecules against $\mathrm{FeSO}_{4}$ was further studied in homogenates from rat brain, liver and kidney to elucidate if the protective effect depends of the nature of the tested tissue. Here we show that xanthones III and V can prevent an 

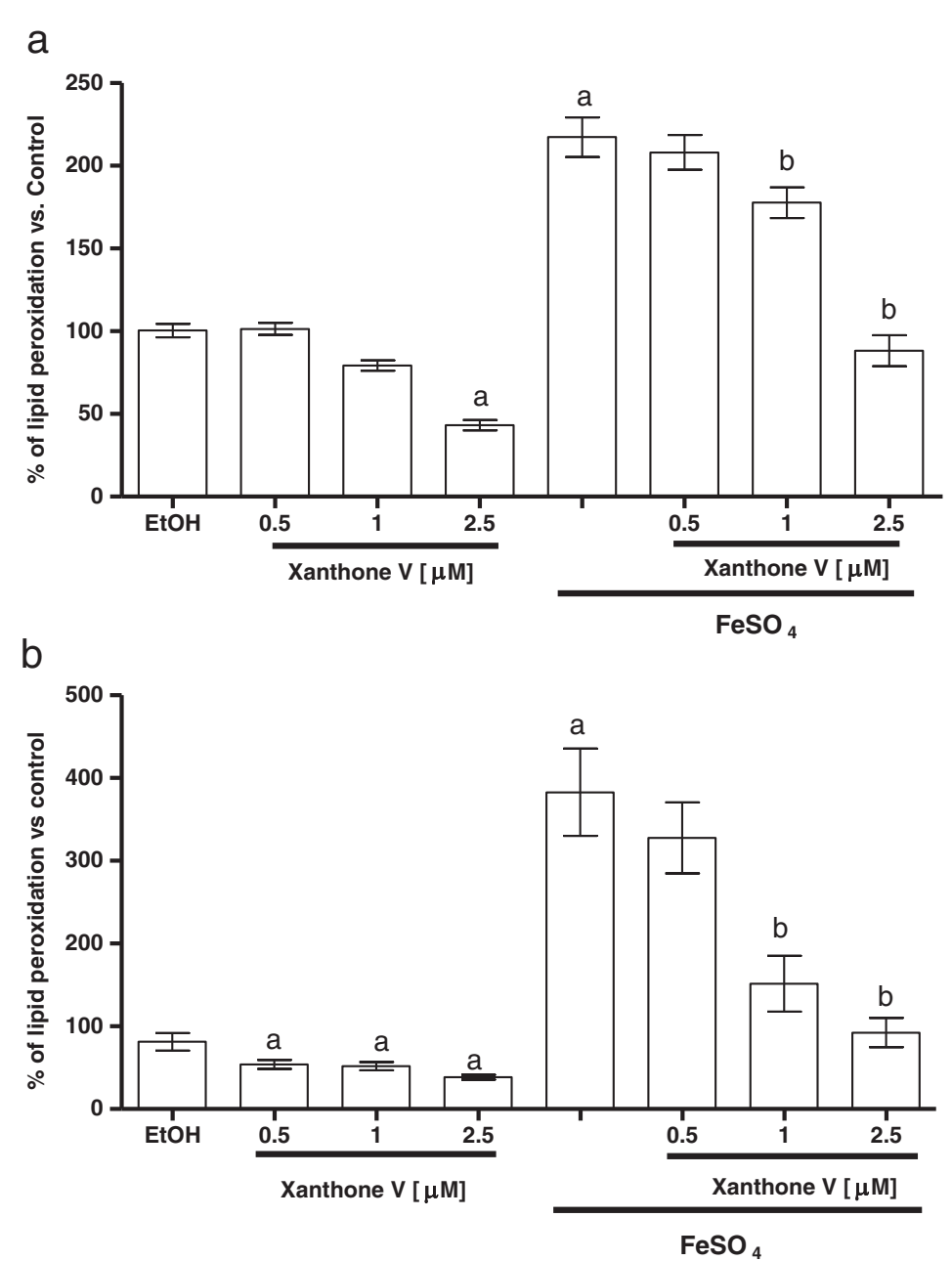

C

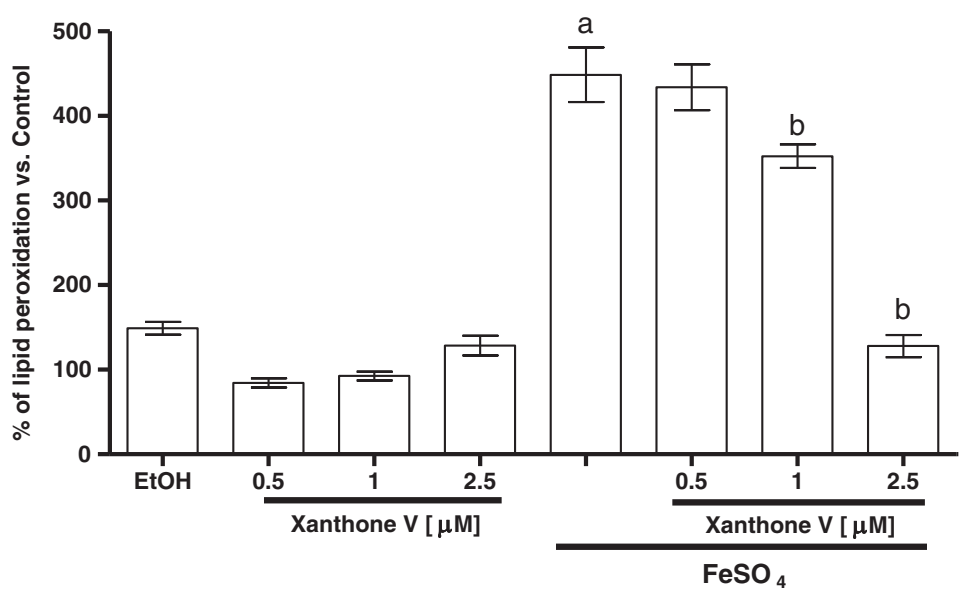

Figure 8 Concentration-response effect of xanthone $\mathbf{V}$ on the lipid peroxidation (LP) induced by $\mathrm{FeSO}_{4}$ in homogenates. a) Forebrain, b) liver and c) kidney homogenates were incubated with $5 \mu \mathrm{M} \mathrm{FeSO}_{4}$ and different concentrations of xanthone $\mathrm{V}(0,0.5,1$ and $2.5 \mu \mathrm{M})$ in $\mathrm{Kreb}$ 's buffer. Control is represented by $100 \%$. In all panels, mean values \pm S.E.M. of six experiments per group are shown. ${ }^{a} \mathrm{P}<0.01 \mathrm{vs}$. control; ${ }^{\mathrm{b}} \mathrm{P}<0.01$ vs. $\mathrm{FeSO}_{4}$.

increase in the levels of the oxidative markers tested, which in turn are related with the scavenging capacity exhibited by these xanthones in synthetic assays.
Interestingly, the antioxidant effect showed by xanthones on ROS production and lipid peroxidation was not dependent on the tissue studied. Moreover, only in 


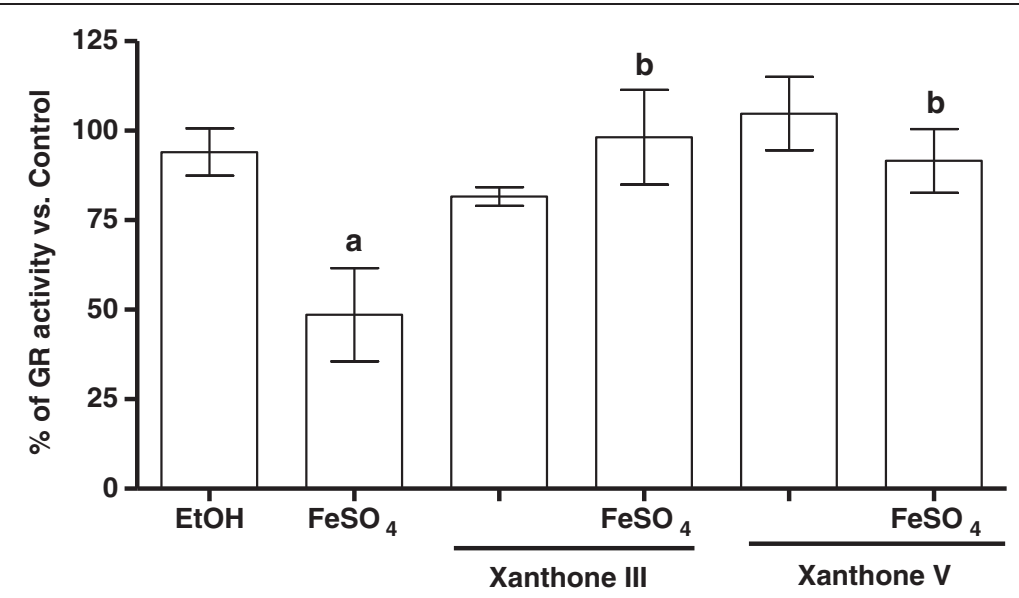

Figure 9 Xanthones III and V prevented the glutathione reductase (GR) activity reduction induced by $\mathrm{FeSO}_{4}$ in brain

homogenates. Forebrain homogenates were incubated with $5 \mu \mathrm{M} \mathrm{FeSO}_{4}$ and $2.5 \mu \mathrm{M}$ xanthones III or $\mathrm{V}$ in Kreb's buffer. Control is represented by $100 \%$. Mean values \pm S.E.M. of three experiments per group are shown. The data are represented as a percentage with respect to control. ${ }^{\mathrm{a}} \mathrm{P}<0.01$ vs control; ${ }^{\mathrm{b}} \mathrm{P}<0.01 \mathrm{vs}$. $\mathrm{FeSO}_{4}$.

brain homogenates, $\mathrm{FeSO}_{4}$ was able to decrease the GR activity, and this effect was prevented by both xanthones. The fact that these xanthones can modulate the GR activity in the brain after the pro-oxidant insult was applied is relevant since the brain is known to be particularly vulnerable to oxidative damage due to its high rate of oxidative metabolic activity, high polyunsaturated fatty acid content, relatively low antioxidant capacity and inadequate neuronal cell repair activity [47]. In this context, GSH is considered the most important endogenous antioxidant in the brain, and GR plays an important role for the conversion of GSSG to GSH. Thus, the evidence collected here suggests that xanthones III and V can be considered as effective antioxidants since they can recover GR activity and were more efficient to scavenge $\mathrm{O}_{2}^{\bullet-}$ than GSH [42]. Thus, since it has been described that different xanthones can modulate a number of physiological molecules $[6,14,16]$, our results suggest that the brain GR can also be a molecular target for xanthone III and V.

Considering that the tested xanthones can exert a protective action on some biomolecules from the oxidative damage in the same magnitude than $\alpha$-mangostin, it is desirable to elucidate specific mechanisms and targets by which these molecules exert their protection, thereby raising expectations on its potential use for therapeutic purposes. Particularly, our group and others have made important descriptions on the properties of $\alpha$-mangostin, a well-known xanthone derived from the pericarp of mangosteen fruit, which has antioxidant and anti-inflammatory properties $[19,21,24,48-51]$. This typically oriental product contrast with the endemic location of Calophyllum brasiliense Cambess, a species geographically located in Latin America. Therefore, the latter constitutes an alternative source of xanthones to be studied and used in alternative medicine around the Occidental hemisphere. Particularly, our study raises considerations on xanthones to be considered as an innovative tool with potential benefits for treatment of those diseases coursing with oxidative stress.

\section{Conclusions}

In summary, this work provides evidence that the natural xanthones III and V possess potential antioxidant properties, although the antioxidant mechanisms through which they exert their actions need to be explored in detail in further studies.

\section{Abbreviations}

ROS: Reactive oxygen species; $\mathrm{O}_{2}^{\bullet-}$ : Superoxide; $\mathrm{OH}^{\bullet}$ : Hydroxyl radical; $\mathrm{H}_{2} \mathrm{O}_{2}$ : Hydrogen peroxide; $\mathrm{ONOO}^{-}$: Peroxynitrite; xanthone III: Jacareubin; xanthone V: 2-(3,3-dimethylallyl)-1,3,5,6-tetrahydroxyxanthone; GR: Glutathione reductase; DCF: 2',7'-dichlorofluorescein; DCFH-DA: 2',7'dichlorodihydrofluorescein diacetate; ABTS: 2,2'-azinobis-(3ethylbenzothiazoline-6-sulfonic acid); DPPH: 2,2-diphenyl-1-picrylhydrazyl; BSA: Bovine serum albumin; DMSO: Dimethylsulfoxide; DTPA: DLpenicillamine, diethylenetriaminepentaacetic acid; NADPH: Nicotinamide adenine dinucleotide reduced form; LP: Lipid peroxidation; MDA: Malondialdehyde; GSSG: Oxidized glutathione; GSH: Glutathione.

\section{Competing interests}

The authors declare that they have no competing interest. The authors alone are responsible for the content and writing of the paper.

\section{Authors' contributions}

BT, carried out the synthetic and biological assays. LR, carried out the DNA and Protein degradation. SEM and RR, carried out the xanthones extraction. $R E$, carried out some of the biological experiments. PB, analyzed and interpreted the data. MO and PE, carried out the enzymatic assays. SL and TC helped to perform the experiment. SD, performed the statistical analysis. PJ, contributed in drafting, revision the manuscript and obtained funding. RC, reviewed and commented on the manuscript for intellectual context. PV, conceived the idea for the study, wrote the body of the text and obtained funding. TM, conceived the idea and design of the study. All of the authors 
read the manuscript, contributed in correcting it and approving its final version.

\section{Acknowledgements}

This work was supported in part by PAPIIT IN210713, and CONACYT Grants 129838,204474 and 183867

\section{Author details}

${ }^{1}$ Departamento de Neuroquímica, Instituto Nacional de Neurología y Neurocirugía Manuel Velasco Suárez, Insurgentes Sur 3877, S.S.A., México, DF 14269, México. ${ }^{2}$ Instituto de Química, Universidad Nacional Autónoma de México, México, DF 04510, México. ${ }^{3}$ Laboratorio de Aminoácidos Excitadores, Instituto Nacional de Neurología y Neurocirugía Manuel Velasco Suárez, S.S. A., México, DF 14269, México. " Laboratorio de Neuroinmunología, Instituto Nacional de Neurología y Neurocirugía Manuel Velasco Suárez, S.S.A., México, DF 14269, México. ${ }^{5}$ Departamento de Biología, Facultad de Química, Universidad Nacional Autónoma de México, México, DF 04510, México. ${ }^{6}$ Laboratorio de Bioquímica Muscular, Instituto Nacional de Rehabilitación, S. S.A., México, DF 14389, México. ${ }^{7}$ Unidad del Bioterio, Facultad de Medicina, Universidad Nacional Autónoma de México, México, DF 04510, México. ${ }^{8}$ Unidad Periférica de Neurociencias Facultad de Medicina UNAM-INNN, México, DF 14269, México.

Received: 12 April 2013 Accepted: 7 October 2013

Published: 11 October 2013

\section{References}

1. Nordberg J, Arner ES: Reactive oxygen species, antioxidants, and the mammalian thioredoxin system. Free Radic Biol Med 2001, 31(11):1287-1312

2. Valko M, Leibfritz D, Moncol J, Cronin MT, Mazur M, Telser J: Free radicals and antioxidants in normal physiological functions and human disease. Int J Biochem Cell Biol 2007, 39(1):44-84.

3. Charles AL, Meyer A, Dal-Ros S, Auger C, Keller N, Gali Ramamoorthy T, Zoll J, Metzger D, Schini-Kerth V, Geny B: Polyphenols prevents aging-related impairment in skeletal muscle mitochondrial function through decreased reactive oxygen species production. Exp Physiol 2012.

4. Corcoran MP, McKay DL, Blumberg JB: Flavonoid basics: chemistry, sources, mechanisms of action, and safety. J Nutr Gerontol Geriatr 2012, 31 (3): $176-189$

5. Widmer RJ, Freund MA, Flammer AJ, Sexton J, Lennon R, Romani A, Mulinacci N, Vinceri FF, Lerman LO, Lerman A: Beneficial effects of polyphenolrich olive oil in patients with early atherosclerosis. Eur J Nutr 2012

6. Gonzalez R, Ballester I, Lopez-Posadas R, Suarez MD, Zarzuelo A, MartinezAugustin O, Sanchez De Medina F: Effects of flavonoids and other polyphenols on inflammation. Crit Rev Food Sci Nutr 2011, 51(4):331-362.

7. Shan T, Ma Q, Guo K, Liu J, Li W, Wang F, Wu E: Xanthones from mangosteen extracts as natural chemopreventive agents: potential anticancer drugs. Curr Mol Med 2011, 11(8):666-677.

8. Campos-Esparza Mdel R, Torres-Ramos MA: Neuroprotection by natural polyphenols: molecular mechanisms. Cent Nerv Syst Agents Med Chem 2010, 10(4):269-277.

9. Lewis WH, McNaughton DR, Goh SH, LeJohn HB, Wright JA: Inhibition of mammalian ribonucleotide reductase by a dinucleotide produced in eucaryotic cells. J Cell Physiol 1977, 93(3):345-352.

10. Duke JA, Vásquez R: Amazonian ethnobotanical dictionary. Boca Raton, Fla: CRC Press; 1994

11. Grenand P: Pharmacopées traditionnelles en Guyane: Créoles, Wayãpi, Palikur Ed. entièrement rev. et complétée edn. Paris: IRD Éditions, Institut de recherche pour le développement; 2004

12. Rutter R: Catalogo de las Plantas Utiles de la Amazonia Peruana. Perú: Instituto Lingüistico de verano; 1990.

13. Katritzky AR, Rees CW: Comprehensive heterocyclic chemistry: the structure, reactions, synthesis, and uses of heterocyclic compounds. 1st edition. Oxford Oxfordshire, New York: Pergamon Press; 1984.

14. Mesia-Vela S, Sanchez RI, Estrada-Muniz E, Alavez-Solano D, Torres-Sosa C, Jimenez M, Estrada, Reyes-Chilpa R, Kauffman FC: Natural products isolated from Mexican medicinal plants: novel inhibitors of sulfotransferases, SULT1A1 and SULT2A1. Phytomedicine 2001, 8(6):481-488.

15. Yasunaka K, Abe F, Nagayama A, Okabe H, Lozada-Perez L, Lopez-Villafranco E, Muniz EE, Aguilar A, Reyes-Chilpa R: Antibacterial activity of crude extracts from Mexican medicinal plants and purified coumarins and xanthones. J Ethnopharmacol 2005, 97(2):293-299.

16. Reyes-Chilpa R, Baggio CH, Alavez-Solano D, Estrada-Muniz E, Kauffman FC, Sanchez Rl, Mesia-Vela S: Inhibition of gastric $\mathrm{H}+, \mathrm{K}+-$ ATPase activity by flavonoids, coumarins and xanthones isolated from Mexican medicinal plants. J Ethnopharmacol 2006, 105(1-2):167-172.

17. Campos-Esparza MR, Sanchez-Gomez MV, Matute C: Molecular mechanisms of neuroprotection by two natural antioxidant polyphenols. Cell Calcium 2009, 45(4):358-368.

18. Martinez A, Galano A, Vargas R: Free radical scavenger properties of alpha-mangostin: thermodynamics and kinetics of HAT and RAF mechanisms. J Phys Chem B 2011, 115(43):12591-12598.

19. Pedraza-Chaverri J, Reyes-Fermin LM, Nolasco-Amaya EG, Orozco-Ibarra M, Medina-Campos ON, Gonzalez-Cuahutencos O, Rivero-Cruz I, Mata R: ROS scavenging capacity and neuroprotective effect of alpha-mangostin against 3-nitropropionic acid in cerebellar granule neurons. Exp Toxicol Pathol 2009, 61(5):491-501.

20. Buelna-Chontal M, Correa F, Hernandez-Resendiz S, Zazueta C, Pedraza-Chaverri J: Protective effect of alpha-mangostin on cardiac reperfusion damage by attenuation of oxidative stress. J Med Food 2011, 14(11):1370-1374.

21. Reyes-Fermin LM, Gonzalez-Reyes S, Tarco-Alvarez NG, Hernandez-Nava M, Orozco-lbarra M, Pedraza-Chaverri J: Neuroprotective effect of alphamangostin and curcumin against iodoacetate-induced cell death. Nut Neurosci 2012, 15(5):34-41.

22. Barcenas-Pazos: Caracterización tecnológica de veinte especies maderables de la Selva Lacandona. Madera y Bosques 1995, 1(1):29.

23. Reyes-Chilpa R, Jimenez-Estrada M, Estrada-Muniz E: Antifungal xanthones from Calophyllum brasiliensis heartwood. J Chem Ecol 1997, 23(7):1901-1911.

24. Marquez-Valadez B, Lugo-Huitron R, Valdivia-Cerda V, Miranda-Ramirez LR, PerezDe La Cruz V, Gonzalez-Cuahutencos O, Rivero-Cruz I, Mata R, Santamaria A, Pedraza-Chaverri J: The natural xanthone alpha-mangostin reduces oxidative damage in rat brain tissue. Nutr Neurosci 2009, 12(1):35-42.

25. Fontana M, Mosca L, Rosei MA: Interaction of enkephalins with oxyradicals. Biochem Pharmacol 2001, 61(10):1253-1257.

26. Floriano-Sanchez E, Villanueva C, Medina-Campos ON, Rocha D, Sanchez Gonzalez DJ, Cardenas-Rodriguez N, Pedraza-Chaverri J: Nordihydroguaiaretic acid is a potent in vitro scavenger of peroxynitrite, singlet oxygen, hydroxyl radical, superoxide anion and hypochlorous acid and prevents in vivo ozone-induced tyrosine nitration in lungs. Free Radic Res 2006, 40(5):523-533.

27. Halliwell B, Gutteridge JM, Aruoma OI: The deoxyribose method: a simple "test-tube" assay for determination of rate constants for reactions of hydroxyl radicals. Anal Biochem 1987, 165(1):215-219.

28. Beckman JS, Chen J, Ischiropoulos H, Crow JP: Oxidative chemistry of peroxynitrite. Methods Enzymol 1994, 233:229-240.

29. Crow JP, Beckman JS: The importance of superoxide in nitric oxidedependent toxicity: evidence for peroxynitrite-mediated injury. Adv Exp Med Biol 1996, 387:147-161.

30. Long LH, Evans PJ, Halliwell B: Hydrogen peroxide in human urine: implications for antioxidant defense and redox regulation. Biochem Biophys Res Commun 1999, 262(3):605-609.

31. Kocha T, Yamaguchi M, Ohtaki H, Fukuda T, Aoyagi T: Hydrogen peroxidemediated degradation of protein: different oxidation modes of copperand iron-dependent hydroxyl radicals on the degradation of albumin. Biochim Biophys Acta 1997, 1337(2):319-326.

32. Galano A, Macias-Ruvalcaba NA, Medina Campos ON, Pedraza-Chaverri J: Mechanism of the $\mathrm{OH}$ radical scavenging activity of nordihydroguaiaretic acid: a combined theoretical and experimental study. J Phys Chem B 2010, 114(19):6625-6635

33. Perez-De La Cruz V, Elinos-Calderon D, Carrillo-Mora P, Silva-Adaya D, Konigsberg M, Moran J, Ali SF, Chanez-Cardenas ME, Perez-De La Cruz G, Santamaria A: Time-course correlation of early toxic events in three models of striatal damage: modulation by proteases inhibition. Neurochem Int 2010, 56(6-7):834-842.

34. Ali SF, LeBel CP, Bondy SC: Reactive oxygen species formation as a biomarker of methylmercury and trimethyltin neurotoxicity. Neurotoxicol 1992, 13(3):637-648.

35. Herrera-Mundo N, Sitges M: Mechanisms underlying striatal vulnerability to 3-nitropropionic acid. J Neurochem 2010, 114(2):597-605.

36. Tapia E, Sanchez-Gonzalez DJ, Medina-Campos ON, Soto V, Avila-Casado C, Martinez-Martinez CM, Johnson RJ, Rodriguez-Iturbe B, Pedraza-Chaverri J, 
Franco M, et al: Treatment with pyrrolidine dithiocarbamate improves proteinuria, oxidative stress, and glomerular hypertension in overload proteinuria. Am J Physiol Renal Physiol 2008, 295(5):F1431-1439.

37. Na Y: Recent cancer drug development with xanthone structures. J Pharm Pharmacol 2009, 61(6):707-712.

38. Minami H, Takahashi E, Fukuyama Y, Kodama M, Yoshizawa T, Nakagawa K Novel xanthones with superoxide scavenging activity from Garcinia subelliptica. Chem Pharm Bull 1995, 43(2):347-349.

39. Pedraza-Chaverri J, Cardenas-Rodriguez N, Orozco-lbarra M, Perez-Rojas JM: Medicinal properties of mangosteen (Garcinia mangostana). Food Chem Toxicol 2008, 46(10):3227-3239.

40. Vieira LM, Kijjoa A: Naturally-occurring xanthones: recent developments. Curr Med Chem 2005, 12(21):2413-2446.

41. Gales L, Damas AM: Xanthones-a structural perspective. Curr Med Chem 2005, 12(21):2499-2515.

42. Lugo-Huitron R, Blanco-Ayala T, Ugalde-Muniz P, Carrillo-Mora P, PedrazaChaverri J, Silva-Adaya D, Maldonado PD, Torres I, Pinzon E, Ortiz-Islas E, et al: On the antioxidant properties of kynurenic acid: free radical scavenging activity and inhibition of oxidative stress. Neurotoxicol Teratol 2011, 33 (5):538-547.

43. Sun D, Zhang $S$, Wei $Y$, Yin L: Antioxidant activity of mangostin in cell-free system and its effect on K562 leukemia cell line in photodynamic therapy. Acta Biochim Biophys Sin 2009, 41(12):1033-1043.

44. Ito C, Itoigawa M, Mishina Y, Filho VC, Mukainaka T, Tokuda H, Nishino H, Furukawa H: Chemical constituents of Calophyllum brasiliensis: structure elucidation of seven new xanthones and their cancer chemopreventive activity. J Nat Prod 2002, 65(3):267-272.

45. Sang S, Lapsley K, Jeong WS, Lachance PA, Ho CT, Rosen RT: Antioxidative phenolic compounds isolated from almond skins (Prunus amygdalus Batsch). J Agric Food Chem 2002, 50(8):2459-2463.

46. Almeida RD, Manadas BJ, Carvalho AP, Duarte CB: Intracellular signaling mechanisms in photodynamic therapy. Biochim Biophys Acta 2004, 1704 (2):59-86.

47. Traystman R, Kirsch JR, Koehler RC: Oxygen radical mechanisms of brain injury following ischemia and reperfusion. J Appl Physiol 1991, 71(4):1185-1195.

48. Sanchez-Perez Y, Morales-Barcenas R, Garcia-Cuellar CM, Lopez-Marure R, Calderon-Oliver M, Pedraza-Chaverri J, Chirino Yl: The alpha-mangostin prevention on cisplatin-induced apoptotic death in LLC-PK1 cells is associated to an inhibition of ROS production and p53 induction. Chem Biol Interact 2010, 188(1):144-150.

49. Chen LG, Yang LL, Wang CC: Anti-inflammatory activity of mangostins from Garcinia mangostana. Food Chem Toxicol 2008, 46(2):688-693.

50. Tewtrakul S, Wattanapiromsakul C, Mahabusarakam W: Effects of compounds from Garcinia mangostana on inflammatory mediators in RAW264.7 macrophage cells. J Ethnopharmacol 2009, 121(3):379-382.

51. Marquez-Valadez B, Maldonado PD, Galvan-Arzate S, Mendez-Cuesta LA Perez-De La Cruz V, Pedraza-Chaverri J, Chanez-Cardenas ME, Santamaria A: Alpha-mangostin induces changes in glutathione levels associated with glutathione peroxidase activity in rat brain synaptosomes. Nutr Neurosci 2012, 15(5):13-19.

doi:10.1186/1472-6882-13-262

Cite this article as: Blanco-Ayala et al: Antioxidant properties of xanthones from Calophyllum brasiliense: prevention of oxidative damage induced by $\mathrm{FeSO}_{4}$. BMC Complementary and Alternative Medicine 2013 13:262.

\section{Submit your next manuscript to BioMed Central and take full advantage of:}

- Convenient online submission

- Thorough peer review

- No space constraints or color figure charges

- Immediate publication on acceptance

- Inclusion in PubMed, CAS, Scopus and Google Scholar

- Research which is freely available for redistribution 